\title{
Effect of Superoxide Dismutase on Semen Parameters and Antioxidant Enzyme Activities of Liquid Stored $\left(5^{\circ} \mathrm{C}\right)$ Mithun (Bos frontalis) Semen
}

\author{
P. Perumal \\ Animal Reproduction Laboratory, National Research Centre on Mithun (ICAR), Jharnapani, Nagaland 797 106, India \\ Correspondence should be addressed to P. Perumal; perumalponraj@gmail.com
}

Received 15 November 2013; Revised 28 January 2014; Accepted 8 February 2014; Published 13 March 2014

Academic Editor: Mustafa N. Bucak

Copyright (c) 2014 P. Perumal. This is an open access article distributed under the Creative Commons Attribution License, which permits unrestricted use, distribution, and reproduction in any medium, provided the original work is properly cited.

\begin{abstract}
The present study was undertaken to assess the effect of superoxide dismutase (SOD) on sperm motility, and viability; total sperm abnormality; acrosomal and plasma membrane integrity; DNA abnormality; antioxidant profiles such as catalase (CAT), reduced glutathione (GSH), and total antioxidant capacity (TAC); enzymatic profiles such as aspartate amino transaminase (AST), and alanine amino transaminase (ALT); and biochemical profiles such as malondialdehyde (MDA) production and cholesterol efflux. Total numbers of 50 ejaculates were collected twice a week from eight mithun bulls and semen was split into four equal aliquots, diluted with the TEYC extender. Group 1: semen without additives (control), and group 2 to group 4: semen was diluted with $50 \mathrm{U} / \mathrm{mL}, 100 \mathrm{U} / \mathrm{mL}$, and $150 \mathrm{U} / \mathrm{mL}$ of SOD, respectively. These seminal parameters, antioxidant, enzymatic, and biochemical profiles were assessed at $5^{\circ} \mathrm{C}$ for $1,6,12,24$, and $30 \mathrm{~h}$ of incubation. Inclusion of SOD into diluent resulted in significant $(P<0.05)$ decrease in percentages of dead spermatozoa, abnormal spermatozoa, and acrosomal abnormalities at different hours of storage periods as compared with control group. Additionally, SOD at $100 \mathrm{U} / \mathrm{mL}$ has significant improvement in quality of mithun semen than SOD at 50 or $150 \mathrm{U} / \mathrm{mL}$ stored in in-vitro for up to $30 \mathrm{~h}$. It was concluded that the possible protective effects of SOD on sperm parameters are that it prevents MDA production and preserves the antioxidants and intracellular enzymes during preservation.
\end{abstract}

\section{Introduction}

Mithun (Bos frontalis) is a semiwild free-range, rare bovine species present in the North-Eastern Hill (NEH) region of India. It is believed to have originated more than 8000 years ago from wild Indian gaur (Bos gaurus) [1]. The animal has an important place in the social, cultural, religious, and economic life of the tribal population particularly in the states of Arunachal Pradesh, Nagaland, Manipur, and Mizoram. Recent statistics indicates that the mithun population is decreasing gradually due to lack of suitable breeding bulls, increase in intensive inbreeding practices, declining land area for grazing, and lack of suitable breeding and feeding management in NEH region. Greater efforts are required from all quarters to preserve the mithun population to enhance the socioeconomic status of this region. Since mithuns are semiwild animals and not fully domesticated, natural breeding is practiced in this species with accompanied limitations like cost and disease transmission. Thus, use of AI for improvement of its pedigree is utmost essential.

Cold storage of semen is used to reduce metabolism and to maintain sperm viability over an extended period of time. But the quality of semen is deteriorated during this extended storage period. One cause of this decline is due to the action of the reactive oxygen species (ROS) generated by the cellular components of semen, abnormal spermatozoa, and by neutrophils, namely, a superoxide anion radical $\left(\mathrm{O}_{2}{ }^{-}\right)$, hydrogen peroxide $\left(\mathrm{H}_{2} \mathrm{O}_{2}\right)[2,3]$ as the sperm membrane has high polyunsaturated fatty acids (PUFA). It results in the inhibition of both sperm ATP production and sperm movement, particularly forward progression [4]. The effects of lipid peroxidation include irreversible a loss in motility, damage to the sperm DNA, and fertility $[2,5]$. Glutathione, 
glutathione peroxidase, reduced glutathione, catalase, superoxide dismutase, vitamin $\mathrm{C}$, vitamin $\mathrm{E}$, and melatonin are the major antioxidants naturally present in mammalian semen against ROS to protect the sperm from lipid peroxidation and to maintain its integrity [6-11]. The levels of antioxidant decreased during the preservation process by dilution of semen with extender and excessive generation of ROS molecules $[9,12]$. Natural and synthetic antioxidant systems have been described as a defense functioning mechanism against lipid peroxidation (LPO) in semen $[13,14]$. Thus, supplementation with natural antioxidants or synthetic antioxidants could reduce the impact of oxidative stress during the sperm storage process and thus improve the quality of chilled semen [15-17].

Superoxide dismutase (SOD) is an antioxidant that catalyzes dismutation of superoxide into oxygen and hydrogen peroxide. It scavenges both extracellular and intracellular superoxide anion and prevents lipid peroxidation of the plasma membrane. SOD spontaneously dismutase $\left(\mathrm{O}_{2}{ }^{-}\right)$ anion to form $\mathrm{O}_{2}$ and $\mathrm{H}_{2} \mathrm{O}_{2}$. SOD also prevents premature hyperactivation and capacitation induced by superoxide radicals before ejaculating [18].

The addition of antioxidants such as SOD to equine sperm [19], bull sperm [20], and buffalo semen [21] has been shown to protect sperm against the harmful effects of ROS and improve sperm motility and membrane integrity during sperm liquid storage or in the unfrozen state.

Further, perusal of literatures revealed that no information and to the best of our knowledge this is the first report of the effect of SOD on seminal parameters, antioxidative enzymatic level, and biochemical profiles in mithun semen. Hence, the objective of this study was to assess the effect of this additive on the seminal parameters and biochemical and enzymatic profiles of mithun semen to pursue future sperm preservation protocols.

\section{Material and Methods}

2.1. Experimental Animals. Eight apparently healthy mithun bulls of approximately 4 to $6 \mathrm{yr}$ of age were selected from the herd derived from various hilly tracts of the $\mathrm{NEH}$ region of India. The average body weight of the bulls was $501 \mathrm{~kg}$ (493 to $507 \mathrm{~kg}$ ) at $4-6 \mathrm{yr}$ of age with good body condition (score 5-6) maintained under uniform feeding, housing, and lighting conditions. Each experimental animal was fed in this experiment as per the farm schedule. Each experimental animal was daily offered ad libitum drinking water, $30 \mathrm{~kg}$ mixed jungle forages (18.4\% dry matter and $10.2 \%$ crude protein), and $4 \mathrm{~kg}$ concentrates $(87.1 \%$ dry matter and $14.5 \%$ crude protein) fortified with mineral mixture and salt. Semen was collected from the animals through rectal massage method [22]. During the study, all the experimental protocols met the Institutional Animal Care and Use Committee regulations.

2.2. Semen Collection and Processing. Total numbers of 58 ejaculates were collected from the eight mithun bulls twice a week with the success rate of $90.62 \%$, of which $86.20 \%$ ejaculates (50 ejaculates) were used for semen processing and analysis. Semen samples were pooled to eliminate individual differences and individual ejaculate volume of semen was between 0.8 and $1.3 \mathrm{~mL}$ and was not sufficient to analyse the seminal parameters and measure the biochemical profiles. Moreover during collection, the initial and end transparent secretions were discarded and only good quality neat semen drops were collected in a graduated test tube with the help of a funnel. Immediately after collection, the samples were kept in a water bath at $37^{\circ} \mathrm{C}$ and routine preliminary evaluations were measured. After the preliminary evaluations, samples were subjected to the initial dilution with prewarmed $\left(37^{\circ} \mathrm{C}\right)$ Tris egg yolk citrate extender (TEYC). The partially diluted samples were then brought to the laboratory in an insulated flask containing warm water $\left(37^{\circ} \mathrm{C}\right)$ for further processing. The ejaculates were evaluated and accepted for evaluation if the following criteria were met: concentration $>500 \mathrm{million} / \mathrm{mL}$; mass activity $>3+$, individual motility $>70 \%$, and total abnormality $<10 \%$.

Each pooled ejaculate was split into four equal aliquots and diluted with the TEYC extender with SOD (SRL, Mumbai, India). Group 1: semen without additives (control) and group 2 to group 4: semen with $50 \mathrm{U} / \mathrm{mL}, 100 \mathrm{U} / \mathrm{mL}$, and $150 \mathrm{U} / \mathrm{mL}$ of SOD, respectively [17]. However, $\mathrm{pH}$ of diluents was adjusted to be 6.8-7.0 by using phosphate buffer solution. Diluted semen samples were kept in glass tubes and cooled from 37 to $5^{\circ} \mathrm{C}$, at a rate of $0.2-0.3^{\circ} \mathrm{C} / \mathrm{min}$ in a cold cabinet and maintained at $5^{\circ} \mathrm{C}$ during liquid storage for up to a $30 \mathrm{~h}$ period of the experiment. The percentage of sperm motility and viability, total sperm abnormality, acrosomal integrity, the plasma membrane integrity by hypoosmotic swelling test (HOST), and DNA integrity by Feulgen staining technique [23] was determined as per standard procedure in samples during storage of semen at $5^{\circ} \mathrm{C}$ for $1,6,12,24$, and $30 \mathrm{~h}$, respectively.

Sperm motility was assessed by analyzing four to five fields of view of sample placed on a prewarmed slide $\left(37^{\circ} \mathrm{C}\right)$ under prewarmed cover slip $\left(37^{\circ} \mathrm{C}\right)$ using bright-field optics (Nikon, Eclipse 80i; magnification 400x). Before determination of progressive motility, the stored samples were warmed in a water bath at $37^{\circ} \mathrm{C}$ for $5 \mathrm{~min}$ [24].

The count of live spermatozoa was determined using eosin-nigrosin stain $[5 \%(\mathrm{w} / \mathrm{v})$ nigrosin water soluble, $0.6 \%$ $(\mathrm{w} / \mathrm{v})$ eosin yellow water soluble, and $3 \%$ sodium citrate dihydrate; filtered and $\mathrm{pH}$ adjusted to 7.0 by adding few drops of $0.1 \mathrm{M} \mathrm{NaH}_{2} \mathrm{PO}_{4}$ or $0.1 \mathrm{M} \mathrm{Na}_{2} \mathrm{HPO}_{4}$ ] according to a previously described method using bright-field optics (Nikon, Eclipse 80i; magnification 1000x) [24]. Spermatozoa (eosin-nigrosin stained; 200 per sample) were also evaluated under brightfield optics (Nikon, Eclipse 80i; magnification 1000x) for morphological abnormalities [24]. Acrosomal integrity was assessed by Giemsa staining as described by Watson [25].

The HOST was used as a complementary test to the viability assessment protocol to evaluate the functional integrity of the sperm plasma membrane. HOST relies on the resistance of the membrane to loss of permeability under stress condition of swelling in a hypoosmotic medium [26]. Sperm cells with resistant membranes exhibited swelling around the tail such that the flagella becomes curled and the membrane maintained a swollen bubble around the curled flagellum. The assay was performed by mixing $30 \mu \mathrm{L}$ of semen with 
a $300 \mu \mathrm{L} 100 \mathrm{mOsm} / \mathrm{kg}$ hypoosmotic solution (9 g fructose plus $4.9 \mathrm{~g}$ sodium citrate per liter of distilled water) [27]. This mixture was incubated $\left(37^{\circ} \mathrm{C}\right)$ for $1 \mathrm{~h}$, and $0.2 \mathrm{~mL}$ of the mixture was placed on a microscope slide and mounted with a cover slip and immediately evaluated (Nikon, Eclipse 80i; 400x magnification) under a phase-contrast microscope. A total of 200 spermatozoa were counted in at least five different microscopic fields. The percentages of sperm with swollen and curled tails were then recorded.

DNA abnormality of sperm was examined by Feulgen staining technique. Semen smears were made at the different hours of incubation and stained by the Feulgen technique [23]. Briefly, the smear was prepared and allowed it to air dry for at least 1 hour, fixed in 10 percent neutral buffered formal saline for 15 minutes and washed in running water for 10 minutes. The smear was hydrolyzed in 5 N HCL for 30 minutes, washed in running water for 5 minutes, and dipped in Schiff's reagent for 30 minutes. The slides were rinsed in sulfate water for 2 minutes and the same was repeated for three times. They were washed in running water for 10 minutes and dried in air and examined at $\times 1000$ under phase-contrast microscope and the percentage of normal and abnormal staining spermatozoa was determined by counting at least 200 cells per sample. Sperm abnormalities found were classified into six categories: pyriform heads, giantrolled-crested heads, pale staining cells, multiple vacuoles, single vacuoles, and clumped nuclear material [28]. Only spermatozoa with clumped nuclear material were classified as abnormally condensed for further comparisons.

\subsection{Biochemical Assays}

2.3.1. Lipid Peroxidation Assay. Lipid peroxidation level of sperm and seminal plasma was measured by determining the malondialdehyde (MDA) production, using thiobarbituric acid (TBA) as per the method of Buege and Aust [29] and modified by Suleiman et al. [30]. The semen sample from the glass tube was taken and centrifuged at $3000 \mathrm{rpm}$ for $15 \mathrm{~min}$ and the seminal plasma was removed. Then the sperm pellet was resuspended in $2 \mathrm{~mL}$ of PBS ( $\mathrm{pH}$ 7.2) or a variable volume to obtain a sperm concentration of $20 \times 10^{6} / \mathrm{mL}$. Lipid peroxide levels were measured in spermatozoa after the addition of $2 \mathrm{~mL}$ of TBA-TCA reagent (15\% w/v TCA, $0.375 \%$ $\mathrm{w} / \mathrm{v}$ TBA and $0.25 \mathrm{NHCL}$ ) to $1 \mathrm{~mL}$ of sperm suspension. The mixture was treated in a boiling water bath for 1 hour. After cooling, the suspension was centrifuged at $3000 \mathrm{rpm}$ for $10 \mathrm{~min}$. The supernatant was then separated, and absorbance was measured at $535 \mathrm{~nm}$. The MDA concentration was determined by the specific absorbance coefficient $(1.56 \times$ $10^{5} \mu \mathrm{mol} / \mathrm{cm}^{3}$ ).

Consider

$$
\begin{aligned}
& \text { MDA produced }\left(\frac{\mu \mathrm{mol}}{\mathrm{mL}}\right) \\
& =\frac{\mathrm{OD} \times 10^{6} \times \text { Total volume }(3 \mathrm{~mL})}{1.56 \times 10^{5} \times \text { Test volume }(1 \mathrm{~mL})} \\
& =\frac{\mathrm{OD} \times 30}{1.56} .
\end{aligned}
$$

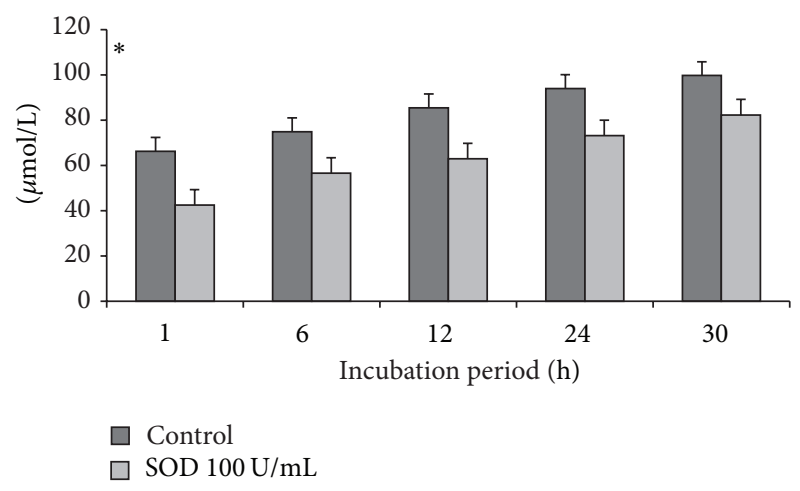

FIGURE 1: AST production in the extended mithun semen containing additive at different storage periods ( ${ }^{*}$ indicates $P<0.05$ ).

2.3.2. Biochemical Profiles. The antioxidant profiles such as CAT, GSH, and TAC; intracellular enzymes such as AST and ALT activity; and cholesterol efflux of the seminal plasma were estimated by commercial available kit.

2.4. Statistical Analysis. The results were analysed statistically and expressed as the mean \pm S.E.M. Means were analyzed by analysis of variance, followed by the Tukey's post hoc test to determine significant differences between the four experimental groups, that is, with additives or no additive for $1,6,12,24$, and $30 \mathrm{~h}$ of storage on the sperm parameters using the SPSS/PC computer program (version 15.0; SPSS, Chicago, IL). Differences with values of $P<0.05$ were considered to be statistically significant after arcsine transformation of percentage data by using SPSS 15 .

\section{Results}

The effects of various doses of SOD on sperm motility (Table 1 ) and viability (Table 2), total sperm abnormality (Table 3), acrosomal (Table 4), plasma membrane (Table 5) integrity, and DNA integrity (Table 6) at different hours of incubation in liquid storage $\left(5^{\circ} \mathrm{C}\right)$ were presented. Results also revealed that the inclusion of SOD into diluent resulted in significant $(P<0.05)$ decrease in percentages of dead spermatozoa, abnormal spermatozoa, and acrosomal abnormalities when semen samples were examined at different hours of storage periods compared with control group. Additionally, SOD at 50 and $150 \mathrm{U} / \mathrm{mL}$ were inferior to SOD $100 \mathrm{U} / \mathrm{mL}$ treatments with regard to these characteristics, and there were significant differences between SOD at 50 and $150 \mathrm{U} / \mathrm{mL}$ in relation to these features. The enzymatic profiles revealed that lowest mean AST (Figure 1) and ALT (Figure 2) were recorded in SOD $(100 \mathrm{U} / \mathrm{mL})$ treated semen than control group and were significantly $(P<0.05)$ differed between groups. Similarly MDA production (Figure 3 ) and cholesterol efflux (Figure 4) were significantly differed between the SOD $(100 \mathrm{U} / \mathrm{mL})$ treated and control untreated group. Antioxidant profiles revealed significantly $(P<0.05)$ higher CAT (Figure 5), GSH (Figure 6), and TAC (Figure 7) in SOD $(100 \mathrm{U} / \mathrm{mL})$ treated semen than control group. It was 
TABLE 1: Mean ( \pm S.E.) motility percentage for mithun semen following storage at $5^{\circ} \mathrm{C}$ for different storage times.

\begin{tabular}{|c|c|c|c|c|c|}
\hline \multirow{2}{*}{ Additives } & \multicolumn{5}{|c|}{ Storage time } \\
\hline & $1 \mathrm{~h}$ & $6 \mathrm{~h}$ & $12 \mathrm{~h}$ & $24 \mathrm{~h}$ & $30 \mathrm{~h}$ \\
\hline Control & $68.27 \pm 1.76^{\mathrm{aE}}$ & $64.00 \pm 1.73^{\mathrm{aD}}$ & $54.16 \pm 1.67^{\mathrm{aC}}$ & $41.36 \pm 1.44^{\mathrm{bB}}$ & $34.72 \pm 1.56^{\mathrm{bA}}$ \\
\hline $\mathrm{SOD} 50 \mathrm{U} / \mathrm{mL}$ & $73.17 \pm 2.24^{\mathrm{bcC}}$ & $68.27 \pm 2.57^{\mathrm{abC}}$ & $59.23 \pm 2.23^{\mathrm{bB}}$ & $45.89 \pm 1.68^{\mathrm{cA}}$ & $40.18 \pm 1.37^{\mathrm{cA}}$ \\
\hline SOD $100 \mathrm{U} / \mathrm{mL}$ & $76.33 \pm 1.57^{\mathrm{cE}}$ & $72.16 \pm 1.74^{\mathrm{bD}}$ & $65.58 \pm 1.83^{\mathrm{cC}}$ & $52.66 \pm 1.52^{\mathrm{dB}}$ & $44.56 \pm 1.42^{\mathrm{dA}}$ \\
\hline SOD $150 \mathrm{U} / \mathrm{mL}$ & $71.29 \pm 1.36^{\mathrm{abE}}$ & $65.88 \pm 1.33^{\mathrm{aD}}$ & $50.92 \pm 1.74^{\mathrm{aC}}$ & $33.28 \pm 1.74^{\mathrm{aB}}$ & $29.50 \pm 1.90^{\mathrm{aA}}$ \\
\hline
\end{tabular}

Within columns means with different letters (a, b, c, d) differ significantly $(P<0.05)$.

Within rows means with different letters $(A, B, C, D, E)$ differ significantly $(P<0.05)$.

TABLE 2: Mean ( \pm S.E.) viable sperm percentage for mithun semen following storage at $5^{\circ} \mathrm{C}$ for different storage times.

\begin{tabular}{lccccc}
\hline Additives & \multicolumn{4}{c}{ Storage time } & \\
& $1 \mathrm{~h}$ & $6 \mathrm{~h}$ & $12 \mathrm{~h}$ & $24 \mathrm{~h}$ & $30 \mathrm{~h}$ \\
\hline Control & $73.03 \pm 1.69^{\mathrm{aE}}$ & $66.44 \pm 1.57^{\mathrm{aD}}$ & $55.45 \pm 2.00^{\mathrm{aC}}$ & $43.36 \pm 2.13^{\mathrm{bB}}$ & $37.40 \pm 1.91^{\mathrm{bA}}$ \\
SOD $50 \mathrm{U} / \mathrm{mL}$ & $74.35 \pm 1.79^{\mathrm{aC}}$ & $71.25 \pm 1.68^{\mathrm{bC}}$ & $63.94 \pm 1.41^{\mathrm{bB}}$ & $44.11 \pm 1.60^{\mathrm{bA}}$ & $40.87 \pm 1.53^{\mathrm{cA}}$ \\
SOD $100 \mathrm{U} / \mathrm{mL}$ & $78.07 \pm 1.44^{\mathrm{bD}}$ & $75.21 \pm 1.40^{\mathrm{cD}}$ & $68.19 \pm 1.61^{\mathrm{cC}}$ & $58.01 \pm 1.87^{\mathrm{cB}}$ & $47.22 \pm 1.60^{\mathrm{dA}}$ \\
SOD $150 \mathrm{U} / \mathrm{mL}$ & $72.70 \pm 1.31^{\mathrm{aC}}$ & $67.88 \pm 1.33^{\mathrm{aD}}$ & $56.99 \pm 2.19^{\mathrm{aC}}$ & $36.80 \pm 1.47^{\mathrm{aB}}$ & $32.21 \pm 1.55^{\mathrm{aA}}$ \\
\hline
\end{tabular}

Within columns means with different letters (a, b, c, d) differ significantly $(P<0.05)$.

Within rows means with different letters $(A, B, C, D, E)$ differ significantly $(P<0.05)$.

TABLE 3: Mean ( \pm S.E.) total abnormal sperm percentage for mithun semen following storage at $5^{\circ} \mathrm{C}$ for different storage times.

\begin{tabular}{lccccc}
\hline Additives & & \multicolumn{3}{c}{ Storage time } \\
& $1 \mathrm{~h}$ & $6 \mathrm{~h}$ & $12 \mathrm{~h}$ & $24 \mathrm{~h}$ & $30 \mathrm{~h}$ \\
\hline Control & $6.16 \pm 0.70^{\mathrm{abA}}$ & $7.75 \pm 0.91^{\mathrm{bA}}$ & $11.41 \pm 1.22^{\mathrm{cB}}$ & $12.92 \pm 1.25^{\mathrm{cBC}}$ & $14.56 \pm 1.30^{\mathrm{cC}}$ \\
SOD $50 \mathrm{U} / \mathrm{mL}$ & $5.99 \pm 0.97^{\mathrm{aA}}$ & $6.87 \pm 0.88^{\mathrm{aA}}$ & $9.52 \pm 1.29^{\mathrm{bB}}$ & $10.94 \pm 1.35^{\mathrm{bBC}}$ & $12.00 \pm 1.28^{\mathrm{bC}}$ \\
SOD $100 \mathrm{U} / \mathrm{mL}$ & $5.59 \pm 0.85^{\mathrm{aA}}$ & $6.76 \pm 0.88^{\mathrm{aB}}$ & $7.78 \pm 0.78^{\mathrm{aB}}$ & $9.06 \pm 1.12^{\mathrm{aC}}$ & $10.13 \pm 1.23^{\mathrm{aC}}$ \\
SOD $150 \mathrm{U} / \mathrm{mL}$ & $6.96 \pm 0.70^{\mathrm{bA}}$ & $8.85 \pm 0.96^{\mathrm{cB}}$ & $10.05 \pm 0.89^{\mathrm{bcC}}$ & $11.70 \pm 1.09^{\mathrm{bcD}}$ & $14.81 \pm 0.99^{\mathrm{cE}}$ \\
\hline
\end{tabular}

Within columns means with different letters (a, b, c, d) differ significantly $(P<0.05)$.

Within rows means with different letters $(A, B, C, D, E)$ differ significantly $(P<0.05)$.

TABLE 4: Mean ( \pm S.E.) Acrosomal integrity (\%) in semen of mithun for different storage times at $5^{\circ} \mathrm{C}$.

\begin{tabular}{lccccc}
\hline Additives & \multicolumn{4}{c}{ Storage time } & \\
& $1 \mathrm{~h}$ & $6 \mathrm{~h}$ & $12 \mathrm{~h}$ & $24 \mathrm{~h}$ & $30 \mathrm{~h}$ \\
\hline Control & $73.62 \pm 1.99^{\mathrm{aE}}$ & $66.31 \pm 1.91^{\mathrm{aD}}$ & $57.08 \pm 1.74^{\mathrm{aC}}$ & $43.83 \pm 1.83^{\mathrm{bB}}$ & $36.03 \pm 1.87^{\mathrm{aA}}$ \\
SOD $50 \mathrm{U} / \mathrm{mL}$ & $79.42 \pm 1.57^{\mathrm{bE}}$ & $74.27 \pm 1.70^{\mathrm{bD}}$ & $66.22 \pm 1.61^{\mathrm{bC}}$ & $56.79 \pm 1.96^{\mathrm{cB}}$ & $43.77 \pm 1.43^{\mathrm{bA}}$ \\
SOD $100 \mathrm{U} / \mathrm{mL}$ & $83.71 \pm 1.76^{\mathrm{cD}}$ & $80.80 \pm 1.77^{\mathrm{cD}}$ & $74.65 \pm 1.20^{\mathrm{cC}}$ & $57.31 \pm 1.72^{\mathrm{cB}}$ & $47.17 \pm 1.57^{\mathrm{cA}}$ \\
SOD $150 \mathrm{U} / \mathrm{mL}$ & $75.25 \pm 1.72^{\mathrm{aD}}$ & $70.93 \pm 1.80^{\mathrm{bC}}$ & $57.36 \pm 1.74^{\mathrm{aB}}$ & $39.34 \pm 1.54^{\mathrm{aA}}$ & $36.05 \pm 1.46^{\mathrm{aA}}$ \\
\hline
\end{tabular}

Within columns means with different letters (a, b, c, d) differ significantly $(P<0.05)$.

Within rows means with different letters $(A, B, C, D, E)$ differ significantly $(P<0.05)$.

TABle 5: Plasma membrane integrity (HOST) ( \pm S.E.) (\%) for extended mithun semen containing additive at different storage times at $5^{\circ} \mathrm{C}$.

\begin{tabular}{lccccc}
\hline Additives & \multicolumn{4}{c}{ Storage iime } & \\
& $1 \mathrm{~h}$ & $6 \mathrm{~h}$ & $12 \mathrm{~h}$ & $24 \mathrm{~h}$ & $30 \mathrm{~h}$ \\
\hline Control & $74.61 \pm 1.41^{\mathrm{abE}}$ & $68.25 \pm 1.51^{\mathrm{aD}}$ & $59.27 \pm 1.84^{\mathrm{bC}}$ & $43.35 \pm 2.33^{\mathrm{bB}}$ & $35.35 \pm 2.19^{\mathrm{aA}}$ \\
SOD $50 \mathrm{U} / \mathrm{mL}$ & $77.54 \pm 1.79^{\mathrm{bD}}$ & $74.17 \pm 1.97^{\mathrm{bD}}$ & $65.13 \pm 1.83^{\mathrm{cC}}$ & $45.90 \pm 1.68^{\mathrm{bB}}$ & $41.55 \pm 1.74^{\mathrm{bA}}$ \\
SOD $100 \mathrm{U} / \mathrm{mL}$ & $82.54 \pm 1.80^{\mathrm{cE}}$ & $78.56 \pm 1.57^{\mathrm{cD}}$ & $73.42 \pm 1.29^{\mathrm{dC}}$ & $58.24 \pm 1.56^{\mathrm{cB}}$ & $50.35 \pm 1.47^{\mathrm{cA}}$ \\
SOD $150 \mathrm{U} / \mathrm{mL}$ & $72.93 \pm 1.86^{\mathrm{aE}}$ & $68.25 \pm 2.26^{\mathrm{aD}}$ & $55.89 \pm 1.51^{\mathrm{aC}}$ & $36.26 \pm 1.27^{\mathrm{aB}}$ & $32.31 \pm 1.40^{\mathrm{aA}}$ \\
\hline
\end{tabular}

Within columns means with different letters (a, b, c, d) differ significantly $(P<0.05)$.

Within rows means with different letters $(A, B, C, D, E)$ differ significantly $(P<0.05)$. 
TABLE 6: DNA integrity ( \pm S.E.) percentage for extended mithun semen containing additive at different storage times at $5^{\circ} \mathrm{C}$.

\begin{tabular}{|c|c|c|c|c|c|}
\hline \multirow{2}{*}{ Additives } & \multicolumn{5}{|c|}{ Storage time } \\
\hline & $1 \mathrm{~h}$ & $6 \mathrm{~h}$ & $12 \mathrm{~h}$ & $24 \mathrm{~h}$ & $30 \mathrm{~h}$ \\
\hline Control & $75.07 \pm 1.98^{\mathrm{aE}}$ & $67.89 \pm 2.00^{\mathrm{aD}}$ & $58.66 \pm 1.61^{\mathrm{aC}}$ & $44.99 \pm 1.79^{\mathrm{bB}}$ & $37.27 \pm 2.01^{\mathrm{aA}}$ \\
\hline $\mathrm{SOD} 50 \mathrm{U} / \mathrm{mL}$ & $80.71 \pm 1.72^{\mathrm{bE}}$ & $76.29 \pm 1.45^{\mathrm{bD}}$ & $67.36 \pm 1.58^{\mathrm{bC}}$ & $58.09 \pm 1.97^{\mathrm{cB}}$ & $45.27 \pm 1.35^{\mathrm{bA}}$ \\
\hline SOD $100 \mathrm{U} / \mathrm{mL}$ & $86.14 \pm 1.87^{\mathrm{cE}}$ & $82.49 \pm 1.78^{\mathrm{cD}}$ & $77.44 \pm 1.18^{\mathrm{cC}}$ & $59.76 \pm 1.69^{\mathrm{cB}}$ & $49.27 \pm 1.59^{\mathrm{cA}}$ \\
\hline SOD $150 \mathrm{U} / \mathrm{mL}$ & $75.99 \pm 1.55^{\mathrm{aE}}$ & $71.67 \pm 1.91^{b D}$ & $59.04 \pm 1.95^{\mathrm{aC}}$ & $41.10 \pm 1.71^{\mathrm{aB}}$ & $37.16 \pm 1.38^{\mathrm{aA}}$ \\
\hline
\end{tabular}

Within columns means with different letters (a, b, c, d) differ significantly $(P<0.05)$. Within rows means with different letters $(A, B, C, D, E)$ differ significantly $(P<0.05)$.

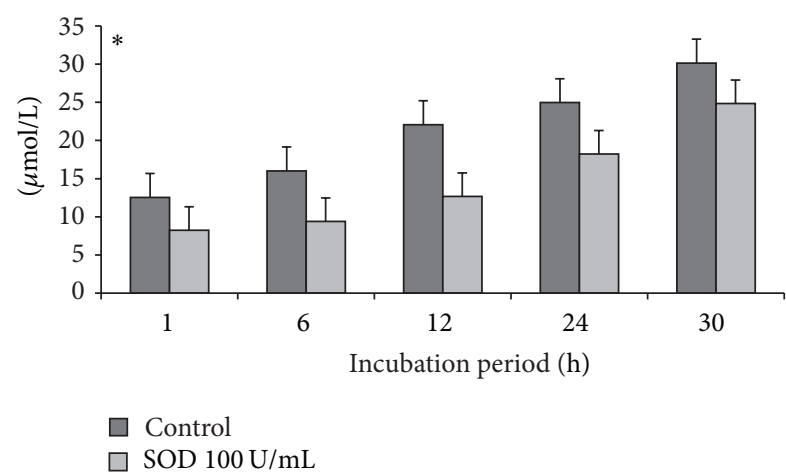

FIGURE 2: ALT production in the extended mithun semen containing additive at different storage periods $\left({ }^{*}\right.$ indicates $\left.P<0.05\right)$.

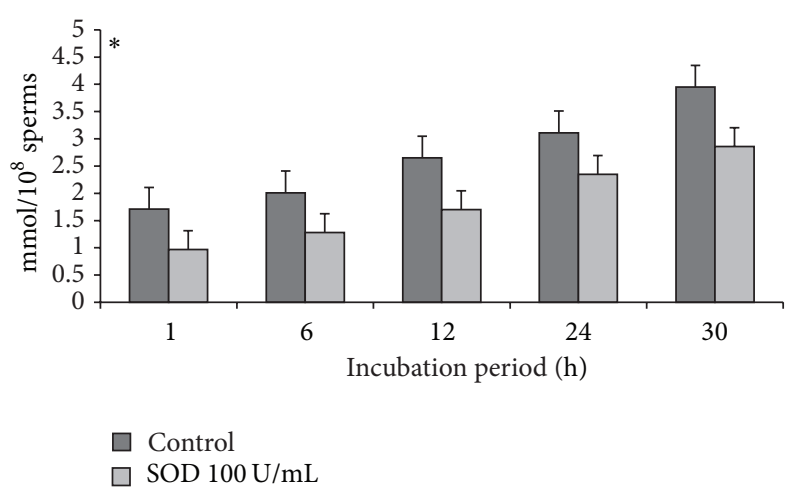

FIGURE 3: MDA production in the extended mithun semen containing additive at different storage periods $\left({ }^{*}\right.$ indicates $\left.P<0.05\right)$.

obvious from the data of this experiment that the addition of SOD especially at the concentrations of $100 \mathrm{U} / \mathrm{mL}$ to the semen diluent resulted in significant improvement in quality, reduction of MDA production, and protection of antioxidant profiles of mithun semen stored in in vitro for up to $30 \mathrm{~h}$.

\section{Discussion}

In the present study, the results revealed that addition of GSH has improved the seminal parameters and enzymatic and biochemical profiles of mithun semen and thus it protects the structures and functions of spermatozoa efficiently. Thus,

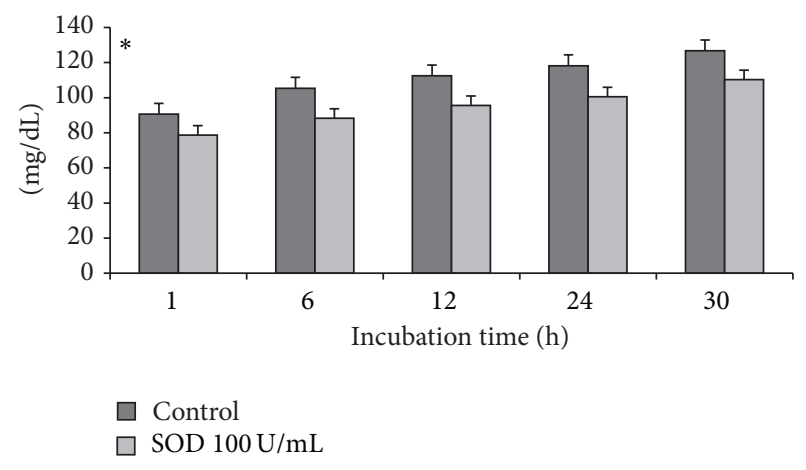

Figure 4: Cholesterol efflux for extended mithun semen containing additive at different storage periods ( ${ }^{*}$ indicates $P<0.05$ ).

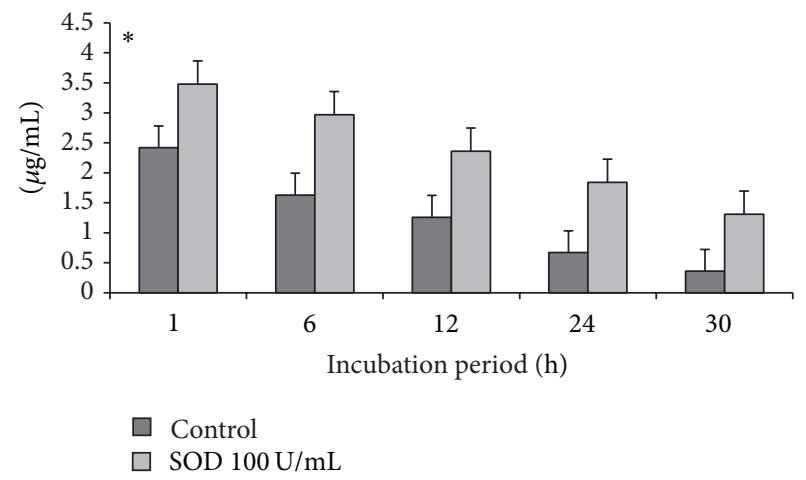

FIgURE 5: CAT production in the extended mithun semen containing additive at different storage periods $\left({ }^{*}\right.$ indicates $\left.P<0.05\right)$.

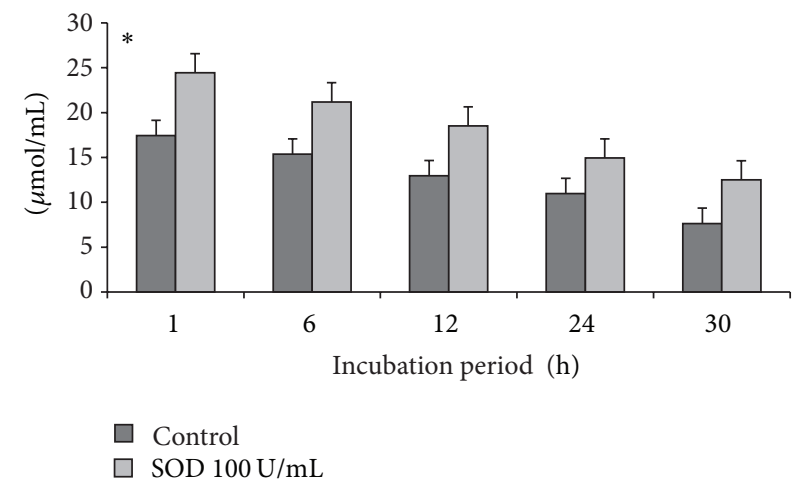

FIGURE 6: GSH production in the extended mithun semen containing additive at different storage periods $\left({ }^{*}\right.$ indicates $\left.P<0.05\right)$. 


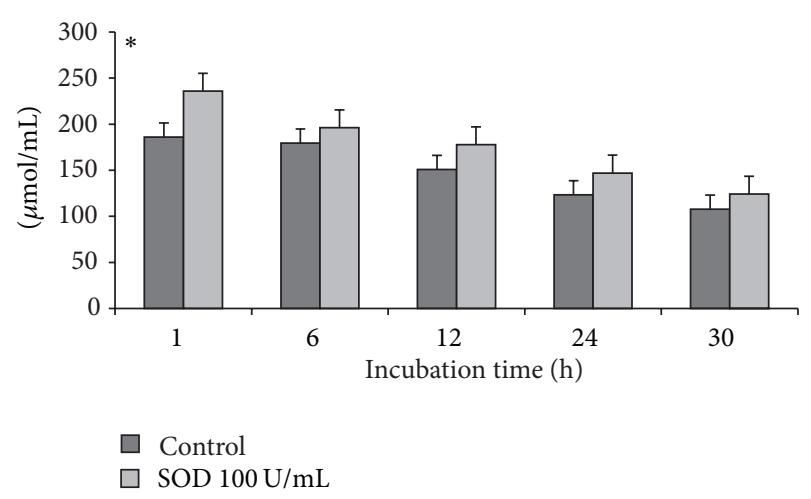

FIgURE 7: TAC production in the extended mithun semen containing additive at different storage periods $\left({ }^{*}\right.$ indicates $\left.P<0.05\right)$.

it may enhance the quality of semen by preserving efficiently during AI procedure.

Analysis of various seminal parameters such as forward progressive motility, livability, acrosomal, plasma membrane integrity, and DNA abnormality are important for extensive utilization of semen in AI. In the present study, SOD supplementation on these parameters revealed significant difference between the treatment groups. The beneficial effects of SOD in semen preservation are due to it being a very potent antioxidant [19-21].

Because the mammalian sperm membrane has high polyunsatured fatty acids (PUFA), it renders the sperm very susceptible to LPO, which occurs as a result of the oxidation of the membrane lipids by partially reduced oxygen molecules, such as superoxide, hydrogen peroxide, and hydroxyl radicals $[4,20]$. Lipid peroxidation of the sperm membrane ultimately leads to the impairment of sperm function due to the attacks by ROS, altered sperm motility and membrane integrity, and damage to sperm DNA and fertility through oxidative stress and the production of cytotoxic aldehydes [31]. In addition, the antioxidant system of seminal plasma and spermatozoa is compromised during semen processing [32]. The levels of antioxidant decreased during the preservation process by dilution of semen with extender and excessive generation of ROS molecules $[9,11]$. Natural and synthetic antioxidant systems have been described as a defense functioning mechanism against lipid peroxidation (LPO) in semen [13]. Therefore, inclusion of exogenous antioxidants with natural antioxidants could reduce the impact of oxidative stress during the sperm storage process, and thus improve the quality of chilled semen $[4,20]$.

The results of the present study showed that addition of $100 \mathrm{U} / \mathrm{mL}$ of SOD improved the keeping quality of mithun semen presented at $5^{\circ} \mathrm{C}$. The sperm motility was declined by the time of storage and remained over $50 \%$ for up to 30 hours. In contrast, decline rate in the motility percentage was higher in semen samples treated with $150 \mathrm{U} / \mathrm{mL}$ SOD or without SOD. It has been reported that the quality of chilled semen decreased with time and remained suitable for use up to 30 hours as judged by motility and morphology [33]. The different effects of the different levels of SOD might be explained according to the report of Cocchia et al. [19] and Shoae and Zamiri [13] showed that the excessive amount of antioxidants caused high fluidity of plasma membrane above the desired point, making sperm more prone to acrosomal damages. In addition, the concentration of antioxidants added to extender should be considered since high dosage of antioxidants may be harmful to spermatozoa due to the change in physiological condition of semen extender. In ram, survival of spermatozoa will increase when the dosage of antioxidant added to extender increases. However, the antioxidant dosage higher than required amount was toxic to spermatozoa [34]. The over expression of SOD may reflect a defect in the development or maturation of spermatozoa, as well as sperm cellular damage, resulting in decreased sperm fertilization potential $[35,36]$. Similarly, in the present study, increasing dosage of SOD, at $150 \mathrm{U} / \mathrm{mL}$ affected the seminal as well as biochemical parameters in mithun semen TEYC extender. At the same time less dosage rate also affected the sperm parameters. Differences in preservation protocols and extender formulations among laboratories, the time of addition/exposure of sperm with antioxidant, concentration of antioxidants, and between species may explain, at least in part, this variability. The improvement of semen quality due to addition of exogenous CAT recorded in the present study was previously reported in the form of motility and intact acrosomal membrane in equine sperm [19], bull sperm [20], and buffalo semen [21]. Moreover, the addition of exogenous SOD was significantly improving the percentages of DNA morphology, sperm viability, and intact plasma membrane (swelling tails) especially at a level of $100 \mathrm{U} / \mathrm{mL}$ of SOD. The highest percentages of intact plasma and acrosomal membranes which were found in the present experiment due to $100 \mathrm{U} / \mathrm{mL}$ SOD may be the reason for better motility in these samples [20,21].

SOD helps maintaining the integrity of normal acrosome [33] and stabilizes the plasmalemma of spermatozoa and so increases motility. SOD, in sperm cells is able to react with many ROS directly for protecting mammalian cells against oxidative stress and hence maintaining sperm motility [6]. Therefore, as seen by this study, attempts to improve the motility and viability of the sperm cells by incorporating SOD in liquid storage $[19,20]$ and frozen semen form have been investigated [21].

A recent report suggested that semen quality is deteriorated [37] by which DNA damage is induced in the male gamete by oxidative stress and spermatozoa are particularly vulnerable to this because they generate ROS and are rich in targets for oxidative attack. The authors also draw attention to the fact that, because spermatozoa are transcriptionally inactive and have little cytoplasm, they are deficient in both antioxidants and DNA-repair systems [38]. Oxidative stress may be a cause of male infertility and contribute to DNA fragmentation in spermatozoa [38]. There are few studies on the effects of antioxidant addition to extenders during cooling and/or freezing mammalian spermatozoa [39]. In mithun semen, ROS are generated mainly by damaged and abnormal spermatozoa and by contaminating leukocytes. Reactive oxygen species damage cells by changes to lipids, proteins, and DNA. Spermatozoa are potentially susceptible to peroxidative 
damage caused by ROS excess due to high amounts of polyunsaturated fatty acids in membrane phospholipids and to sparse cytoplasm. In the present study, addition of SOD has reduced the DNA fragmentation especially at $100 \mathrm{U} / \mathrm{mL}$ in mithun semen preservation at $5^{\circ} \mathrm{C}$ for $30 \mathrm{hrs}$.

Moreover, it maintains plasma and mitochondrial membrane integrity and cytoskeleton structure of flagella of sperm as cell protecting effects. SOD also protects GSH, CAT, and TAC level in the semen extender, which helps to maintain membrane transportation [32] and fertility of the spermatozoa.

It also prevents efflux of cholesterol from the sperm membrane and MDA production in diluent, indicates it prevents premature capacitation and premature acrosomal reaction as acts as an antioxidant [20]. Along with phospholipids, cholesterol is necessary for cell physical integrity and ensures fluidity of the cell membrane [40]. Cholesterol plays a special role in the sperm membrane because its release from the sperm membrane initiates the key step in the process of capacitation and acrosome reaction that is crucial for fertilization [41]. Moreover, adding cholesterol to diluents prior to defreezing increases sperm resistance to stress caused by the freezing-defreezing procedures, preserving sperm motility, and fertilization potential [42]. In the present study, the efflux of cholesterol and MDA production were decreased in treated group as compared to the control untreated group [20]. So the semen samples treated with SOD will have high cryoresistance power than untreated control group. In the present study, it was observed that sperm parameters that were received at $100 \mathrm{U} / \mathrm{mL}$ of SOD were significantly higher than those of the other and control group.

The enzyme such as AST and ALT levels in seminal plasma is very important for sperm metabolism as well as sperm function [43], as it provides energy for survival and motility and fertility of spermatozoa and these transaminase activities in semen are good indicators of semen quality because they measure sperm membrane stability [44]. Thus, increasing the percentage of abnormal spermatozoa in the preservation causes high concentration of transaminase enzyme in the extra cellular fluid due to sperm membrane damage and ease of leakage of enzymes from spermatozoa [45]. Moreover, increase in AST and ALT activities of seminal plasma and semen in liquid storage stage may be due to structural instability of the sperm [46]. In the present study, AST and ALT levels were lower in semen preserved at $100 \mathrm{U} / \mathrm{mL}$ of SOD at different storage period as it stabilises the membrane integrity of acrosome, plasma, mitochondria, and flagella of the sperm.

Glutathione (L-g-glutamyl-L-cysteinylglycine) is the most abundant nonprotein thiol in mammalian cells and is present mainly in reduced form (GSH) and only a small amount is in oxidized form (GSSG). Glutathione antioxidant system consists of reduced glutathione (GSH), oxidized glutathione (GSSG), glutathione reductase (GRX), glutathione peroxidase (GPX), and glutathione-s-transferase. GRX stimulates the reduction of GSSG to GSH. This ensures a steady supply of the reductive substrate (NADPH) to GPX. Glucose-6phosphate dehydrogenase (G6PD) is required for the conversion of NADP to NADPH in GSH oxidization-reduction cycle in sperm and seminal plasma. In the present study GSH was higher in the seminal plasma of SOD added semen as it maintains the antioxidant system in liquid storage of mithun semen.

Similarly CAT is an antioxidant, a tetramer of four polypeptide chain antioxidants found in nearly all living organisms exposed to oxygen. It is derived from the epididymis and seminal vesicle and detoxifies both intracellular and extracellular hydrogen peroxide by reduces $\mathrm{H}_{2} \mathrm{O}_{2}$ to $\mathrm{H}_{2} \mathrm{O}$ and $\mathrm{O}_{2}$, by eliminating the potential ROS toxicity [47] and it can reduce the loss of motility caused by leukocyte generated ROS [48]. It scavenges both extracellular and intracellular superoxide anion and prevents lipid peroxidation of the plasma membrane. CAT also prevents premature hyperactivation and capacitation induced by superoxide radicals before ejaculating [16]. In the present study, the concentration of CAT was higher in SOD treated semen. But normally, seminal plasma is a potent source of this antioxidant, SOD [49]. The high levels of readily peroxidizable polyunsaturated material expose spermatozoa to excessive oxidative stress and the superoxide dismutase activity of sperm samples is a good predictor of their survival time. SOD, when applied at a dose of $100 \mathrm{U} / \mathrm{mL}$, has improved sperm motility during preservation and displayed antioxidative properties, elevating the CAT level, in association with GSH and TAC concentration. Further, SOD, a permeating cryoprotectant, acts as an antioxidant and causes membrane lipid and protein rearrangement, which results in increased membrane fluidity, greater dehydration at lower temperatures, and therefore increased ability of spermatozoa to survive during this preservation [50]. This could be one of the reasons for improved motility, viability and plasma and acrosome membrane and DNA integrity of spermatozoa, diluted in presence of SOD in the semen extender.

\section{Conclusion}

In this study, improvements observed in sperm quality may be attributed to prevention of excessive generation of free radicals, produced by spermatozoa themselves, by means of their antioxidant property of SOD. It was concluded that the possible protective effects of SOD supplementation are that it enhances the antioxidant enzymes content and prevents efflux of cholesterol and phospholipids from cell membrane and MDA production. Thus it may protect the spermatozoa during preservation and enhancing of the fertility in this species. Future, sperm preservation/cryoprotective studies are warranted to confirm the present findings.

\section{Conflict of Interests}

The author declares that there is no conflict of interests regarding the publication of this paper.

\section{References}

[1] F. J. Simoons, "Gayal or mithun," in Evolution of Domesticated Animals, I. L. Manson, Ed., pp. 34-36, Longman, London, UK, 1984. 
[2] P. Perumal, S. Selvaraju, S. Selvakumar et al., "Effect of prefreeze addition of cysteine hydrochloride and reduced glutathione in semen of crossbred jersey bulls on sperm parameters and conception rates," Reproduction in Domestic Animals, vol. 46, no. 4, pp. 636-641, 2011.

[3] P. Peruma, S. Selvaraju, A. K. Barik, D. N. Mohanty, S. Das, and P. C. Mishra, "Role of reduced glutathione in improving post-thawed frozen seminal characters of poor freezable Jersey crossbred bull semen," Indian Journal of Animal Sciences, vol. 81, no. 8, pp. 807-810, 2011.

[4] S. P. Dandekar, G. D. Nadkarni, V. S. Kulkarni, and S. Punekar, "Lipid peroxidation and antioxidant enzymes in male infertility," Journal of Postgraduate Medicine, vol. 48, no. 3, pp. 186-189, 2002.

[5] W. M. C. Maxwell and P. F. Watson, "Recent progress in the preservation of ram semen," Animal Reproduction Science, vol. 42, no. 1-4, pp. 55-65, 1996.

[6] J.-F. Bilodeau, S. Blanchette, C. Gagnon, and M.-A. Sirard, "Thiols prevent $\mathrm{H}_{2} \mathrm{O}_{2}$-mediated loss of sperm motility in cryopreserved bull semen," Theriogenology, vol. 56, no. 2, pp. 275-286, 2001.

[7] J. Gadea, E. Sellés, M. A. Marco et al., "Decrease in glutathione content in boar sperm after cryopreservation: effect of the addition of reduced glutathione to the freezing and thawing extenders," Theriogenology, vol. 62, no. 3-4, pp. 690-701, 2004.

[8] M. N. Bucak, A. Ateşşahin, and A. Yüce, "Effect of anti-oxidants and oxidative stress parameters on ram semen after the freezethawing process," Small Ruminant Research, vol. 75, no. 2-3, pp. 128-134, 2008.

[9] S. Andrabi, "Factors affecting the quality of cryopreserved buffalo (Bubalus bubalis) bull spermatozoa," Reproduction in Domestic Animals, vol. 44, no. 3, pp. 552-569, 2009.

[10] S. Akhter, B. A. Rakha, M. S. Ansari, S. M. H. Andrabi, and N. Ullah, "Storage of Nili-Ravi Buffalo (Bubalus bubalis) semen in skim milk extender supplemented with ascorbic acid and aTocopherol," Pakistan Journal of Zoology, vol. 43, no. 2, pp. 273277, 2011.

[11] P. Perumal, K. Vupru, and K. Khate, "Effect of addition of melatonin on the liquid storage $\left(5^{\circ} \mathrm{C}\right)$ of mithun (Bos frontalis) Semen," International Journal of Zoology, vol. 2013, Article ID 642632, 10 pages, 2013.

[12] R. Kumar, G. Jagan Mohanarao, A. Arvind, and S. K. Atreja, "Freeze-thaw induced genotoxicity in buffalo (Bubalus bubalis) spermatozoa in relation to total antioxidant status," Molecular Biology Reports, vol. 38, no. 3, pp. 1499-1506, 2011.

[13] A. Shoae and M. J. Zamiri, "Effect of butylated hydroxytoluene on bull spermatozoa frozen in egg yolk-citrate extender," Animal Reproduction Science, vol. 104, no. 2-4, pp. 414-418, 2008.

[14] P. Jayaganthan, P. Perumal, T. C. Balamurugan et al., "Effects of Tinospora cordifolia supplementation on semen quality and hormonal profile of ram," Animal Reproduction Science, vol. 140, no. 1, pp. 47-53, 2013.

[15] P. Perumal, K. Vupru, and C. Rajkhowa, "Effect of addition of taurine on the liquid storage $\left(5^{\circ} \mathrm{C}\right)$ of mithun (Bos frontalis) semen," Veterinary Medicine International, vol. 2013, Article ID 165348, 7 pages, 2013.

[16] S. Sarıözkan, G. Türk, F. Cantürk, A. Yay, A. Eken, and A. Akçay, "The effect of bovine serum albumin and fetal calf serum on sperm quality, DNA fragmentation and lipid peroxidation of the liquid stored rabbit semen," Cryobiology, vol. 67, no. 1, pp. 1-6, 2013.
[17] P. Peruma, J. K. Chamuah, and C. Rajkhowa, "Effect of catalase on the liquid storage of mithun (Bos frontalis) semen," Asian Pacific Journal of Reproduction, vol. 2, no. 3, pp. 209-214, 2013.

[18] E. De Lamirande and C. Gagnon, "Impact of reactive oxygen species on spermatozoa: a balancing act between beneficial and detrimental effects," Human Reproduction, vol. 10, no. 1, pp. 1521, 1995.

[19] N. Cocchia, M. P. Pasolini, R. Mancini et al., "Effect of sod (superoxide dismutase) protein supplementation in semen extenders on motility, viability, acrosome status and ERK (extracellular signal-regulated kinase) protein phosphorylation of chilled stallion spermatozoa," Theriogenology, vol. 75, no. 7, pp. 1201-1210, 2011.

[20] R. Asadpour, R. Jafari, and H. Tayefi-Nasrabadi, "The effect of antioxidant supplementation in semen extenders on semen quality and lipid peroxidation of chilled bull spermatozoa," Iranian Journal of Veterinary Research, vol. 13, no. 3, pp. 246249, 2012.

[21] G. A. El-Sisy, W. S. El-Nattat, and R. I. El-Sheshtawy, "Effect of superoxide dismutase and catalase on viability of cryopreserved buffalo spermatozoa," Global Veterinaria, vol. 2, no. 2, pp. 65-61, 2008.

[22] C. W. Palmer, L. F. C. Brito, A. A. Arteaga, L. Söderquist, Y. Persson, and A. D. Barth, "Comparison of electroejaculation and transrectal massage for semen collection in range and yearling feedlot beef bulls," Animal Reproduction Science, vol. 87, no. 1-2, pp. 25-31, 2005.

[23] A. D. Barth and R. J. Oko, "Preparation of semen for morphological examination," in Abnormal Morphology of Bovine Spermatozoa, pp. 8-18, Iowa State University Press, Ames, Iowa, USA, 1989.

[24] N. S. Tomar, Artificial Insemination and Reproduction of Cattle and Buffalos, Sarojprakashan, Allahabad, India, 1997.

[25] P. F. Watson, "Use of a Giemsa stain to detect changes in acrosomes of frozen ram spermatozoa," Veterinary Record, vol. 97, no. 1, pp. 12-15, 1975.

[26] W. M. Buckett, R. G. Farquharson, M. J. M. Luckas, C. R. Kingsland, I. A. Aird, and D. I. Lewis-Jones, "The hypo-osmotic swelling test in recurrent miscarriage," Fertility and Sterility, vol. 68, no. 3, pp. 506-509, 1997.

[27] S. G. Revell and R. A. Mrode, "An osmotic resistance test for bovine semen," Animal Reproduction Science, vol. 36, no. 1-2, pp. 77-86, 1993.

[28] A. D. Barth and R. J. Oko, "Defects of the sperm head," in Abnormal Morphology of bovine Spermatozoa, pp. 130-192, Iowa State University Press, Ames, Iowa, USA, 1989.

[29] J. A. Buege and S. D. Aust, "Microsomal lipid peroxidation," Methods in Enzymology, vol. 52, pp. 302-310, 1978.

[30] S. A. Suleiman, M. Elamin Ali, Z. M. S. Zaki, E. M. A. El-Malik, and M. A. Nasr, "Lipid peroxidation and human sperm motility: protective role of vitamin E," Journal of Andrology, vol. 17, no. 5, pp. 530-537, 1996.

[31] J. F. Griveau, E. Dumont, P. Renard, J. P. Callegari, and D. Le Lannou, "Reactive oxygen species, lipid peroxidation and enzymatic defence systems in human spermatozoa," Journal of Reproduction and Fertility, vol. 103, no. 1, pp. 17-26, 1995.

[32] J. G. Alvarez and B. T. Storey, "Evidence for increased lipid peroxidative damage and loss of superoxide dismutase activity as a mode of sublethal cryodamage to human sperm during cryopreservation," Journal of Andrology, vol. 13, no. 3, pp. 232$241,1992$. 
[33] K. Urata, H. Narahara, Y. Tanaka, T. Egashira, F. Takayama, and I. Miyakawa, "Effect of endotoxin-induced reactive oxygen species on sperm motility," Fertility and Sterility, vol. 76, no. 1, pp. 163-166, 2001.

[34] W. M. C. Maxwell and T. Stojanov, "Liquid storage of ram semen in the absence or presence of some antioxidants," Reproduction, Fertility and Development, vol. 8, no. 6, pp. 1013-1020, 1996.

[35] A. Zalata, T. Hafez, and F. Comhaire, "Evaluation of the role of reactive oxygen species in male infertility," Human Reproduction, vol. 10, no. 6, pp. 1444-1451, 1995.

[36] M. Gavella, V. Lipovac, M. Vučić, and B. Ročić, "Relationship of sperm superoxide dismutase-like activity with other spermspecific enzymes and experimentally induced lipid peroxidation in infertile men," Andrologia, vol. 28, no. 4, pp. 223-229, 1996.

[37] R. J. Aitken, G. N. De Iuliis, J. M. Finnie, A. Hedges, and R. I. McLachlan, "Analysis of the relationships between oxidative stress, DNA damage and sperm vitality in a patient population: development of diagnostic criteria," Human Reproduction, vol. 25, no. 10, pp. 2415-2426, 2010.

[38] J. Aitken and H. Fisher, "Reactive oxygen species generation and human spermatozoa: the balance of benefit and risk," BioEssays, vol. 16, no. 4, pp. 259-267, 1994.

[39] M. Kankofer, G. Kolm, J. Aurich, and C. Aurich, "Activity of glutathione peroxidase, superoxide dismutase and catalase and lipid peroxidation intensity in stallion semen during storage at 5 C," Theriogenology, vol. 63, no. 5, pp. 1354-1365, 2005.

[40] N. Srivastava, S. K. Srivastava, S. K. Ghosh, Amit Kumar, P. Perumal, and A. Jerome, "Acrosome membrane integrity and cryocapacitation are related to cholesterol content of bull spermatozoa," Asian Pacific Journal of Reproduction, vol. 2, no. 2, pp. 126-131, 2013.

[41] T. S. Witte and S. Schäfer-Somi, "Involvement of cholesterol, calcium and progesterone in the induction of capacitation and acrosome reaction of mammalian spermatozoa," Animal Reproduction Science, vol. 102, no. 3-4, pp. 181-193, 2007.

[42] A. I. Moore, E. L. Squires, and J. K. Graham, "Adding cholesterol to the stallion sperm plasma membrane improves cryosurvival," Cryobiology, vol. 51, no. 3, pp. 241-249, 2005.

[43] D. E. Brooks, "Biochemistry of the male accessory glands," in Marshall's Physiology of Reproduction, G. E. Lamming, Ed., pp. 569-690, Churchill Livingstone, Edinburgh, UK, 4th edition, 1990.

[44] J. M. Corteel, "Effects du plasma séminal sur la survie et la fertilité des spermatozoids conservés in vitro," Reproduction Nutrition Development, vol. 20, no. 4, pp. 1111-1123, 1980.

[45] M. Gündoǧan, "Some reproductive parameters and seminal plasma constituents in relation to season in Akkaraman and Awassi rams," Turkish Journal of Veterinary and Animal Sciences, vol. 30, no. 1, pp. 95-100, 2006.

[46] R. B. Buckland, "The activity of six enzymes of chicken seminal plasma and sperm. 1. Effect of in vitro storage and full sib families on enzyme activity and fertility," Poultry Science, vol. 50, no. 6, pp. 1724-1734, 1971.

[47] J. Aitken, "Mechanisms of prevention of lipid peroxidation in human spermatozoa," in Human Acrosome Reaction, P. Fenichel and J. Parinaud, Eds., pp. 339-353, 1995.

[48] E. De Lamirande, H. Jiang, A. Zini, H. Kodama, and C. Gagnon, "Reactive oxygen species and sperm physiology," Reviews of Reproduction, vol. 2, no. 1, pp. 48-54, 1997.
[49] M. Kobayashi, T. Kakizono, and S. Nagai, "Astaxanthin production by a green alga, Haematococcus pluvialis accompanied with morphological changes in acetate media," Journal of Fermentation and Bioengineering, vol. 71, no. 5, pp. 335-339, 1991.

[50] W. V. Holt, "Fundamental aspects of sperm cryobiology: the importance of species and individual differences," Theriogenology, vol. 53, no. 1, pp. 47-58, 2000. 

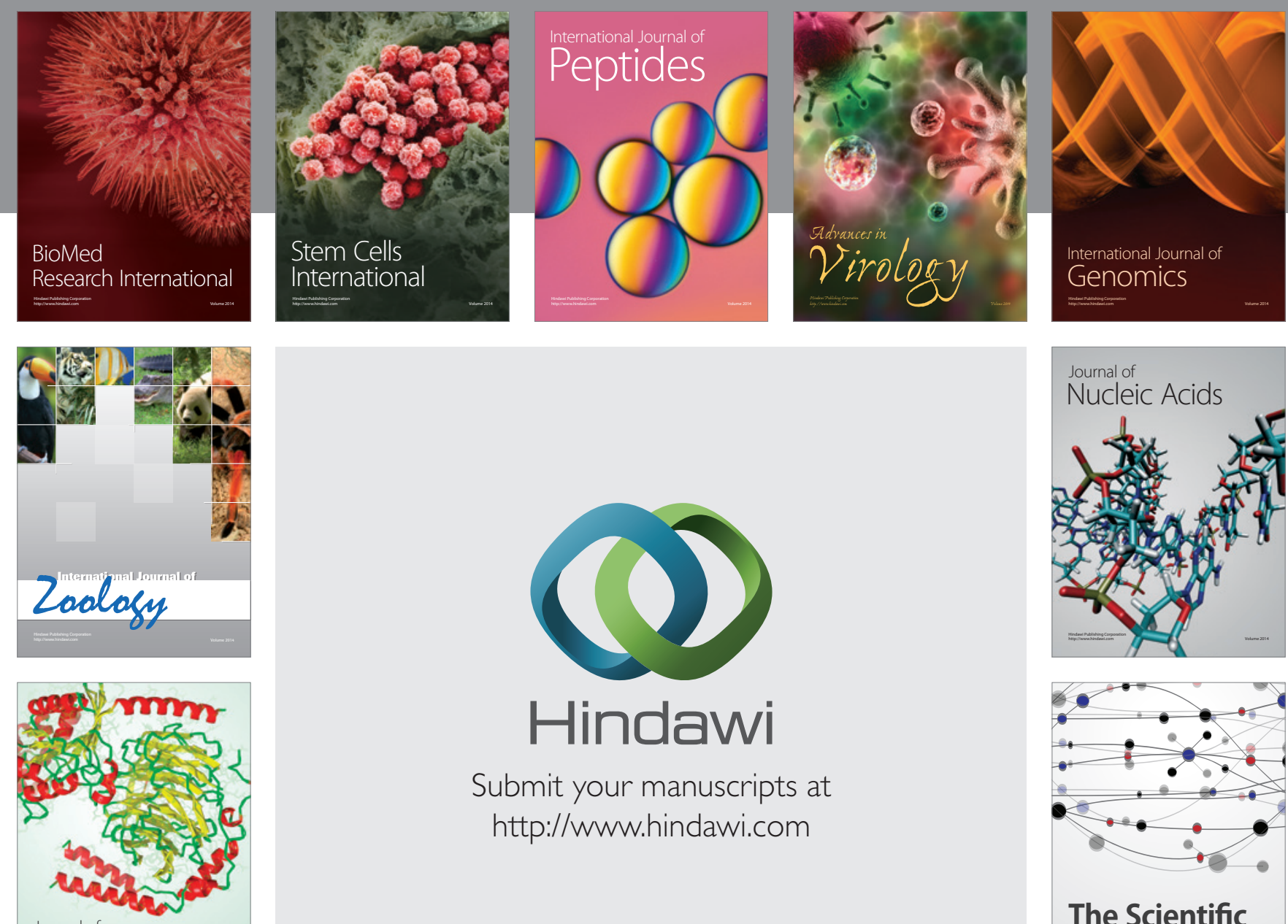

Submit your manuscripts at

http://www.hindawi.com

Journal of
Signal Transduction
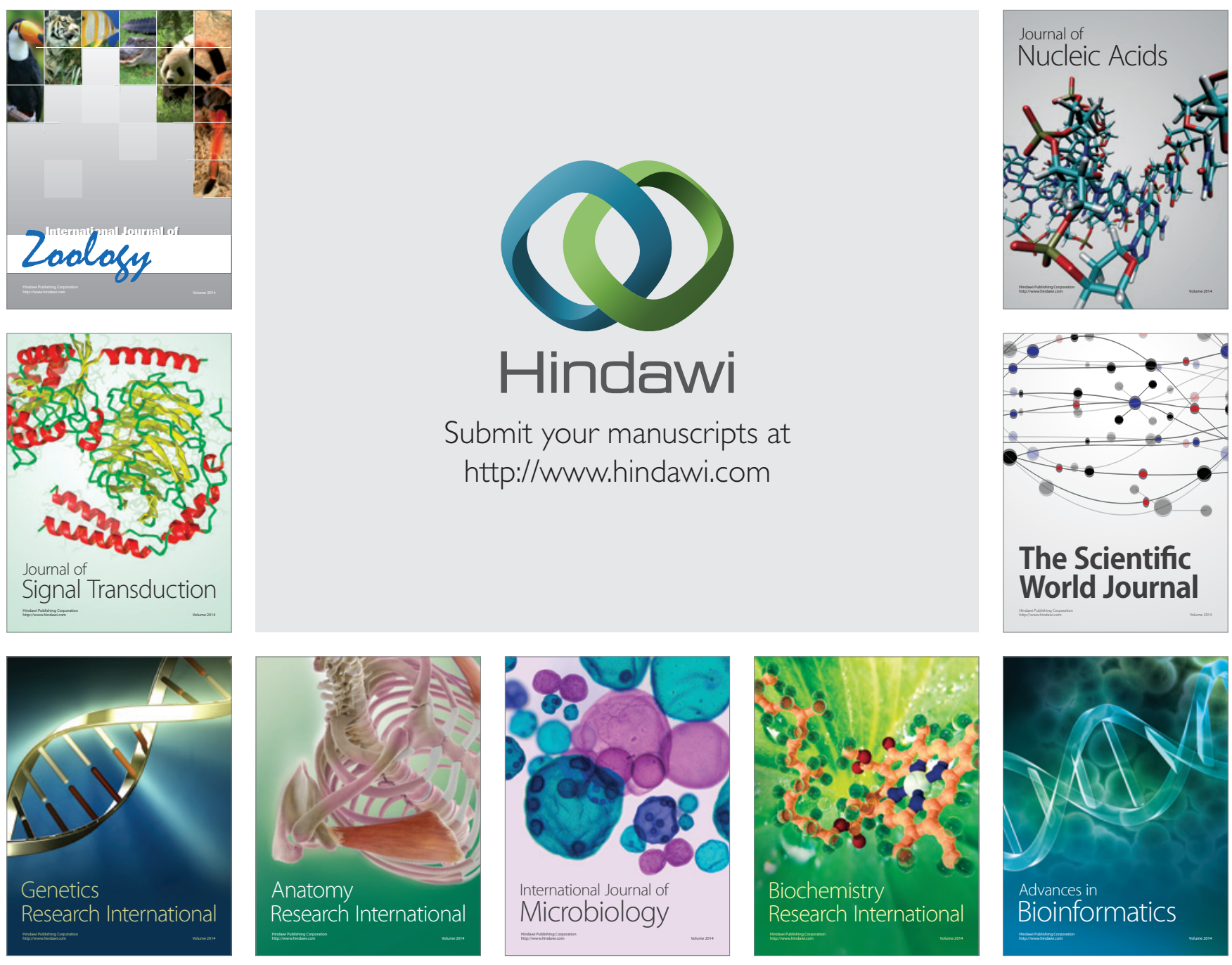

The Scientific World Journal
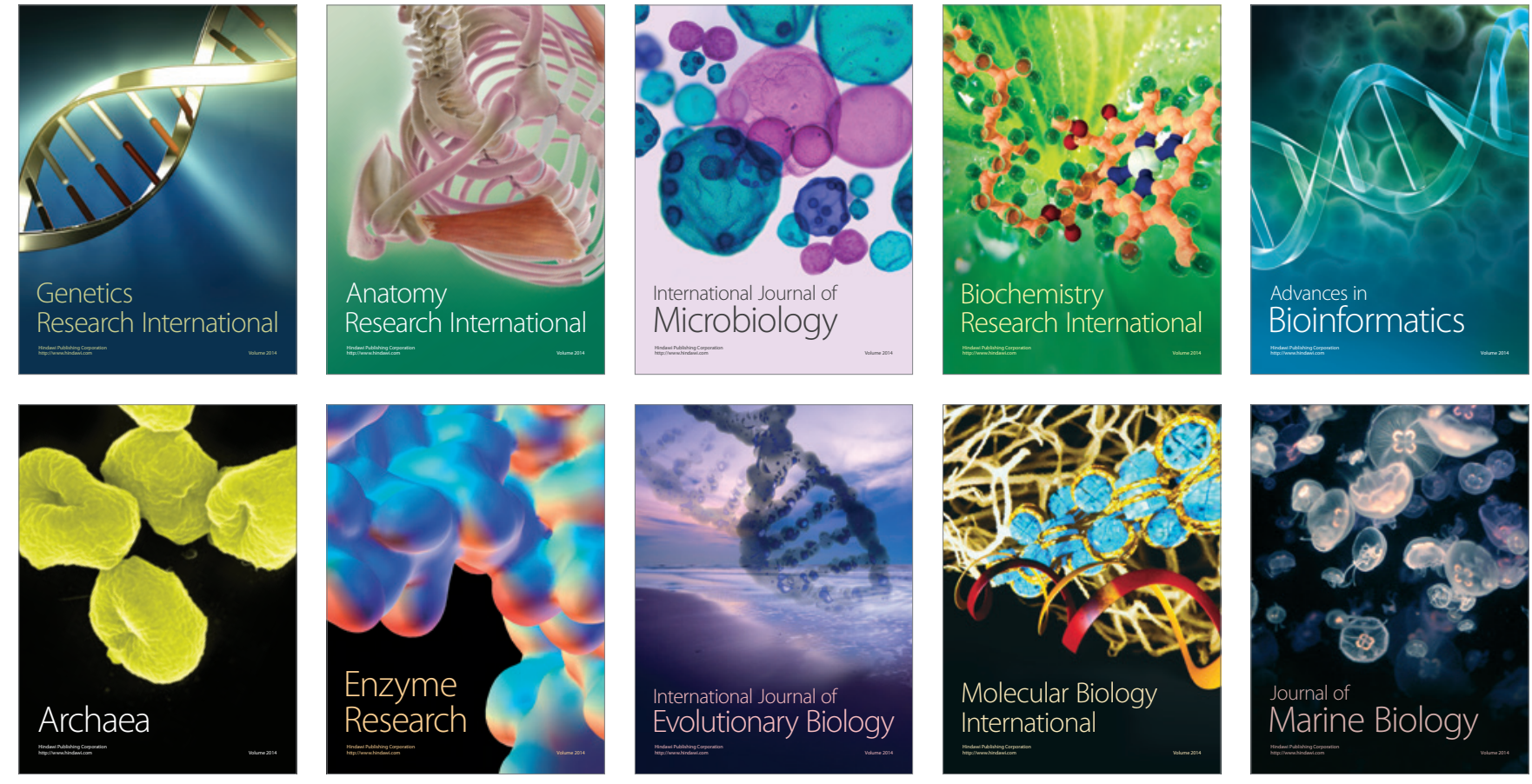